\section{Sampling Damage to Tree Fine Roots: Comparing Air Excavation and Hydropneumatic Elutriation}

\author{
Kevin R. Kosola ${ }^{1}$, Beth Ann A. Workmaster, and James S. Busse \\ Department of Horticulture, University of Wisconsin, 1575 Linden Dr., \\ Madison, WI 53706
}

Jeffrey H. Gilman

Department of Horticultural Science, University of Minnesota, 1970 Folwell Ave., St. Paul, MN 55108

Additional index words. hypodermis, air spade, air knife, root anatomy, apple, Acer pensylvanicum, Betula nigra, Phellodendron amurense, Thuja plicata, Quercus bicolor

Abstract. Air excavation is commonly used to expose structural roots of trees, but its suitability for sampling fine roots for research has not been closely examined. We compared damage and root-diameter class distribution in roots sampled by air excavation with roots sampled by hydropneumatic elutriation of soil cores. We collected samples from six different tree species with a range of fine root diameters: Amur corktree (Phellodendron amurense Rupr.), apple [Malus sylvestris var. domestica (Borkh.) Mansf.], river birch (Betula nigra L.), striped maple (Acer pensylvanicum L.), swamp white oak (Quercus bicolor Willd.), and western redcedar (Thuja plicata D. Don). Root-diameter class distributions for each species were the same for samples collected by either air excavation or by elutriation. Median root diameter was greatest for Amur corktree and western redcedar $(\approx 0.5 \mathrm{~mm})$, intermediate in striped maple and oak, and least in river birch and apple $(\approx 0.2 \mathrm{~mm})$. Root damage was primarily due to loss of root tips. Although species varied in their susceptibility to root damage and whether air excavation caused more damage than elutriation, root diameter was not a good predictor of damage during sampling. Air excavation caused $\approx 26 \%$ greater damage to root samples of river birch and western redcedar than did elutriation. Both sampling methods caused equivalent root damage in all other species. Root anatomy influenced susceptibility to damage during sampling. Epifluorescence microscopy revealed a root hypodermis in all species except Amur corktree and western redcedar. Without the mechanical support of this suberized layer, the cortex of Amur corktree was easily stripped from the stele, leading to extensive damage by both sampling methods. Hydropneumatic root elutriation conferred some protection to roots relative to air excavation (in two of six species); final choice of root sampling method must depend upon the requirements of the individual study and characteristics of the site.

Sampling fine roots from mature trees for experimental analyses of physiological and morphological traits (e.g., Brundrett et al., 1990; Comas et al., 2002; Guo et al., 2004; King et al., 2005; Kosola et al., 2001, 2006; Pregitzer et al., 1997) or monitoring root health (e.g., Rizzo et al., 1998) is timeconsuming. The most commonly character-

Received for publication 25 Oct. 2006. Accepted for publication 4 Dec. 2006.

Research partially supported by a John Z. Duling grant from the Tree Research and Education Endowment Fund.

The use of any product in this study does not constitute an official endorsement by the University of Wisconsin or the University of Minnesota to the exclusion of others that may be suitable.

We thank Calvin Lietzow, Sam McGowan, Anna Schott, Matt Stasiak, Dick Weidmann, Chad Giblin, and the 2005 TRE crew for technical assistance. Thanks also to John Stier and Laura Jull for manuscript review.

${ }^{1}$ To whom reprint requests should be addressed; e-mailkkosola@facstaff.wisc.edu. pneumatic root elutriation was developed to provide recovery of up to $95 \%$ of roots of all size classes from soil cores with minimal damage and good repeatability (Smucker et al., 1982). In this method, air is bubbled up through a flowing water column to carry roots and organic matter up to a capture screen.

High-velocity air excavation of roots is an alternative method for root sampling that allows relatively rapid isolation of roots from an individual tree; it is usually not feasible to identify the origin of roots taken from a soil core. The use of air excavation to expose structural roots is a well-established method in arboriculture to expose girdling roots and remove excess soil from root collars of trees planted too deeply (Smiley, 1999). This method has also been used in analyses of root-disease distribution in orchards (Rizzo et al., 1998) and for excavation of root systems to apply instruments to measure sap flow (Nadezhdina and Cermak, 2003). In air excavation, a stream of pressurized, highspeed air is applied to penetrate soil pores, leaving roots largely intact. Current tools provide about mach 3 air, if supplied with high-pressure air $\left(6.21 \times 10^{5} \mathrm{~Pa}, 7.1 \times\right.$ $\left.10^{-2} \mathrm{~m}^{3} \cdot \mathrm{s}^{-1}\right)$ that penetrates soil pores and shatters soil aggregates, while leaving nonporous objects, like roots, intact.

Fine-root recovery by air excavation of pear trees apparently caused the loss of roots $<0.5 \mathrm{~mm}$ diameter, but detailed descriptions of root damage were lacking (Rizzo and Gross, 2000). Does air excavation cause more damage than the standard method of hydropneumatic elutriation? In this paper, we examine fine-root samples from tree species with a range of root diameters sampled by either air excavation or hydropneumatic elutriation of soil cores. We compared root damage and root-diameter class distribution in fine-root samples collected by these two methods.

\section{Materials and Methods}

We collected root samples from six different tree species with a range of fine-root diameters (Table 1). We collected samples at two dates and locations; from apples in Wisconsin in May 2004, and from five tree species growing in Minnesota in Aug. 2005.

We sampled roots from apple trees [Malus sylvestris var. domestica (Borkh.) Mansf.] at the University of Wisconsin Peninsular Agricultural Experiment Station near Sturgeon Bay (lat. 4452'51.96" N, long. $\left.87^{\circ} 20^{\prime} 7.8^{\prime \prime} \mathrm{E}\right)$ on 13 May 2004. The soil type was an Emmet sandy loam. The trees were planted in 1994 as part of a rootstock trial of 'Gala' apple; we sampled roots from trees grafted on M9, M26, or M27 rootstock (roots sampled from seven, five, and nine trees of each rootstock, respectively).

We collected two soil cores $(6 \mathrm{~cm}$ diameter, $15 \mathrm{~cm}$ deep) at randomly chosen locations within the drip line of each tree. Soil cores were kept on ice in the field and then stored at $-4{ }^{\circ} \mathrm{C}$ for up to 8 weeks before hydropneumatic root elutriation (Gillison's
Table 1. Median root diameter for roots collected from each species. ${ }^{\mathrm{z}}$

\begin{tabular}{lc}
\hline Species & $\begin{array}{c}\text { Median root } \\
\text { diam }(\mathrm{mm})\end{array}$ \\
\hline Amur corktree & $0.43 \mathrm{c} \pm 0.02$ \\
Apple & $0.23 \mathrm{a} \pm 0.02$ \\
River birch & $0.22 \mathrm{a} \pm 0.02$ \\
Striped maple & $0.28 \mathrm{~b} \pm 0.02$ \\
Swamp white oak & $0.23 \mathrm{ab} \pm 0.03$ \\
Western redcedar & $0.47 \mathrm{c} \pm 0.02$ \\
\hline
\end{tabular}

${ }^{\mathrm{z}}$ Values followed by a different letter $(\mathrm{a}, \mathrm{b}, \mathrm{c})$ are significantly different (Fisher's protected LSD, $P<$ 0.05 ). Effects of sampling type (air excavation or elutriation) were not significant. 
Variety Fabrication, Benzonia, Mich.). The extracted roots were stored in $50 \%$ ethanol at $4{ }^{\circ} \mathrm{C}$ until analysis. Tree roots were separated from other species on the basis of morphological traits observed in roots sampled by air excavation.

Air excavation (Air Spade, Concept Engineering Group, Verona, $\mathrm{Pa}$., 90/150 nozzle, $6.21 \times 10^{5} \mathrm{~Pa}, 7.1 \times 10^{-2} \mathrm{~m}^{3} \cdot \mathrm{s}^{-1}$ air compressor) was used to remove soil from roots adjacent to each soil core, exposing largediameter structural roots and clusters of small-diameter lateral roots attached to them. Soil was removed to $\approx 15 \mathrm{~cm}$ depth. In each of the two air excavations for each tree, we collected at least two clusters of lateral roots undamaged by coring. Samples from within each air excavation were pooled, placed in plastic bags, and stored on ice in the field. Within $8 \mathrm{~h}$, roots were transferred into $150-\mathrm{mL}$ containers of $24 \%$ ethanol (used for safety during shipping). The ethanol solution was replaced with $50 \%$ ethanol within 1 week, and samples were stored at $4{ }^{\circ} \mathrm{C}$ until analysis.

We also collected roots from five tree species growing at the University of Minnesota Tree Research and Extension (UMN

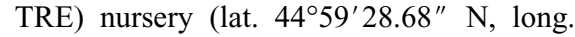
$\left.93^{\circ} 7^{\prime} 16.68^{\prime \prime} \mathrm{E}\right)$ on Waukegan silt loam soil. The samples were collected on 8 Aug. 2005. Trees were planted in 1997. The species we sampled were Amur corktree (Phellodendron amurense Rupr., five trees), river birch (Betula nigra L., seven trees), striped maple (Acer pensylvanicum L., ten trees), swamp white oak (Quercus bicolor Willd., four trees), and western redcedar (Thuja plicata D. Don, eight trees). Each species was planted in a single row. The rows of Amur corktree, striped maple, and western redcedar were adjacent to each other. The rows of river birch and swamp white oak were planted adjacent to each other but were $\approx 100 \mathrm{~m}$ west of the other trees sampled.

For elutriation, a single soil core was collected $25 \mathrm{~cm}$ from the trunk of the tree, in a randomly chosen direction from the trunk. For air-excavation samples, we collected at least two clusters of roots adjacent to each soil core and pooled them into a single sample container. All other sample processing protocols were carried out as described for the samples collected in Wisconsin. Volumetric soil water content was measured with a 12-cm-deep time-domain reflectrometry probe (HydroSense CD 620, Campbell Scientific, Logan, Utah) $25 \mathrm{~cm}$ from the trunk of each tree on the day of sampling.

Root integrity and diameter-distribution analyses. We observed the physical integrity of root tips - the finest, most distal root segments in each sample-with a dissecting microscope at up to $20 \times$ magnification. Root tips were classified as damaged if the stele was exposed or if the root tip was missing entirely. We observed at least 100 root tips in each sample.

We used an automated root scanning and analysis system (WinRhizo Pro, Regent Instruments, Montreal) to characterize root- diameter distribution in all samples. Roots were stained with neutral red $\left(0.5 \mathrm{~g} \cdot \mathrm{L}^{-1}\right) 24 \mathrm{~h}$ before scanning (Bouma et al., 2000). WinRhizo Pro was set to characterize root length and diameter of individual root section links, as defined in Fitter (1987).

Root anatomy. Roots were cleared in $75 \%$ (by volume) lactic acid overnight at $60{ }^{\circ} \mathrm{C}$ and stained with pararosaniline hydrochloride (Boke, 1970) to reveal the presence of a hypodermis. Following dehydration through an ethanol series, tissue was mounted in methyl salicylate on glass slides. Roots were viewed with a Nikon Diaphot inverted epifluorescence microscope (Nikon Instruments, Melville, N.Y.) with a 478-495 nm excitation filter (FITC filter set 31001; Chroma Technology Corp., Brattleboro, Vt.).

Statistical analysis. The effect of sampling type (air excavation vs. elutriated soil core) on root damage was analyzed in SAS as a mixed-model ANOVA (PROC MIXED, ver. 9.1, SAS Institute, Cary, N.C.), with sampling treatment as a fixed variable and tree location as a random variable. Each species was analyzed separately, as the sampling design would partially confound location effects and species effects on root damage. For apples for which we collected two subsamples of each type from each tree, a nested ANOVA was carried out, with subsamples nested within tree. We used the nonparametric Kolmogorov-Smirnoff test to compare the root diameter class distribution for roots collected by air excavation and by soil core elutriation within each species, as these distributions were non-normal. Differences among species in median root diameters from the two types of sampling methods were compared by a two-way ANOVA (PROC MIXED, ver. 9.1, SAS Institute).

\section{Results}

Median root diameter was greatest in samples of Amur corktree and western redcedar, intermediate in striped maple and oak, and least in river birch and apple (Table 1). Root-diameter class distribution was not significantly different between roots sampled by air excavation and roots sampled from soil cores $(P<0.05$, Fig. 1$)$.

We found relatively little root damage in the apple root samples. There was no significant difference in root damage incited by the two sampling methods for apple roots $\left(\mathrm{F}_{1,16}=\right.$ 1.7, $P=0.2$; Fig. 2) and no significant difference among the different apple rootstocks $\left(\mathrm{F}_{2,16}=0.08, P=0.92\right.$; data not shown). Because there was no significant difference in root damage among apple rootstocks, we pooled all apple data for the final analysis, leading to a larger total sample size for apples compared with all other species.

In contrast, there was substantial root damage in all samples collected from the UMN TRE nursery. Air excavation caused significantly more root damage than did soil core elutriation in samples from western redcedar and river birch $(P<0.05$; Fig. 2$)$; root damage did not differ significantly between the two sampling methods in roots from striped maple, Amur corktree, or swamp white oak $(P<0.05$; Fig. 2$)$. The level of root damage varied among species but was generally higher than for apple. Only striped maple had $<40 \%$ root tip damage. Diameter class distribution was not significantly different between roots sampled by air excavation and roots sampled from soil cores for any of the species (Fig. 1).

Soil volumetric water content (measured by TDR) varied significantly among the different tree plots but was not significantly related to root damage (data not shown). There was no significant regression between soil water content and root damage for either sampling type $(P>0.80)$.

Root damage typically consisted of root tip loss, incited by a transverse break in both air-excavated roots and elutriated roots. The exception to this pattern was in Amur corktree, where the root cortex was relatively fragile and easily slipped off the stele, regardless of the collection method. Cortical loss like this is sometimes a symptom of the presence of root rot incited by Phytophthora cinnamomi Rands. Although the cortex did break easily, the cortical cellular breakdown characteristic of root rots was not evident in the field. Phytophthora was not present in root samples taken from three of the Amur corktrees used in this study (data not shown). We did not test for the presence of other root rots.

Epifluorescense microscopy revealed that Amur corktree fine roots lacked a hypodermis. Western redcedar also lacked a hypodermis; however, numerous tracheids were evident in the root cortex. A hypodermis with suberized radial walls was most pronounced in striped maple, but this was also present in apple, river birch, and swamp white oak.

\section{Discussion}

Root damage was greater in the samples collected from the Minnesota site than in the apple roots collected from the Wisconsin site. It is not clear which factors are responsible for the differences in root damage seen between the samples from the two sampling locations, as several plant and soil characteristics differed among the sites. The Wisconsin samples were collected in spring from dormant trees in soil at field capacity. Roots were collected from within a 2-m-wide weedfree strip around the trees, maintained throughout the life of the planting by herbicide applications. The Minnesota samples were collected in midsummer (8 Aug. 2005) from actively growing trees in unsaturated soil. Although the trees had been planted in a weed-free strip, at the time we sampled, there was substantial grass growth around the Acer and Phelloderma trees and some weed growth around the other tree species. Additionally, the silt loam soil at the Minnesota site had a higher clay and silt content than did the sandy loam soil at the Wisconsin site. We speculate that soil aggregates were stronger in the silt loam soil and so were more strongly 


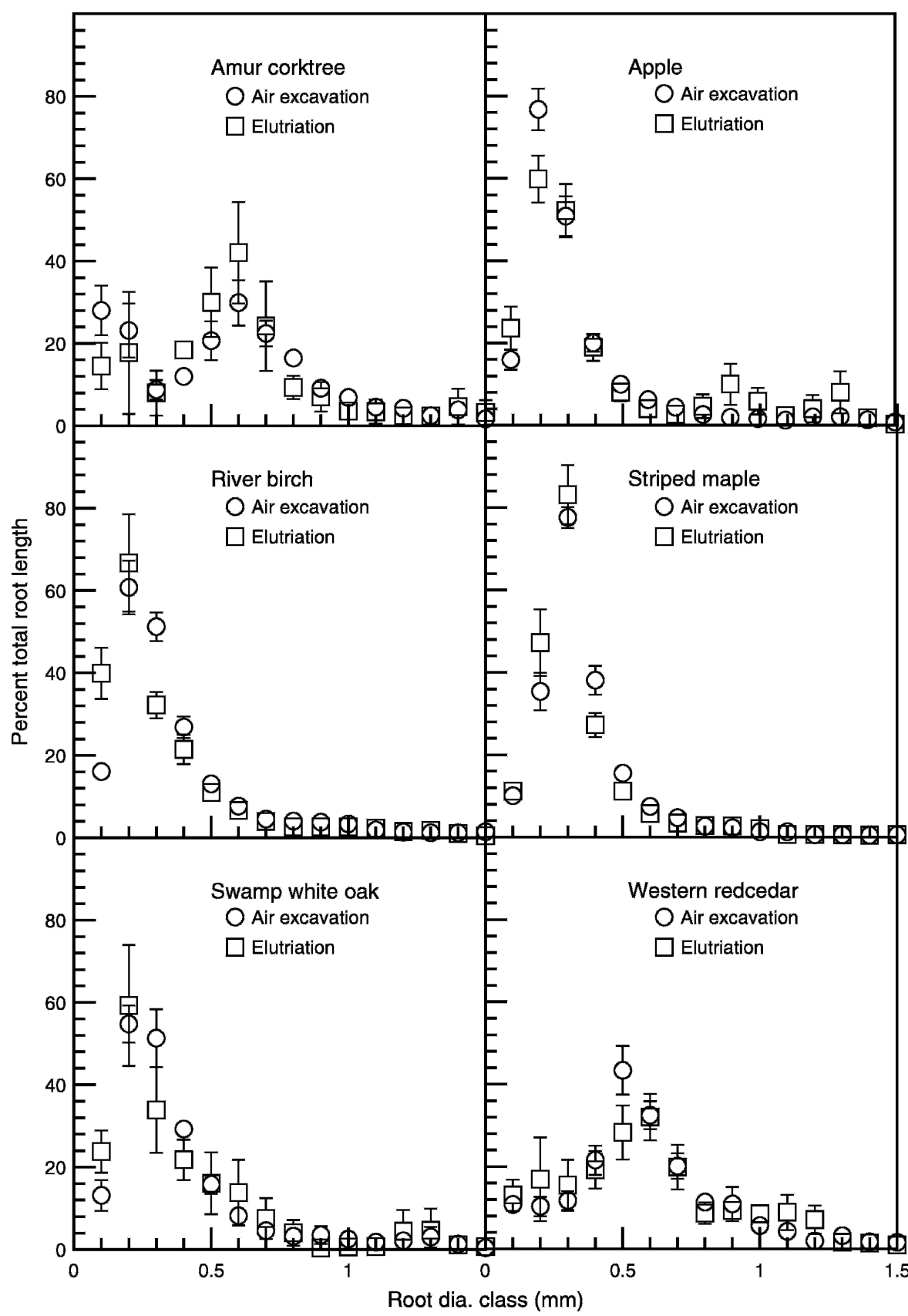

Fig. 1. Root diameter-class distribution. Roots obtained by air excavation $(O)$ or hydropneumatic elutriation of a soil core $(\square)$. Roots were scanned for analysis of diameter-class distribution (0.1-mm increments) with WinRhizo Pro. Values are mean \pm SE. Samples collected in Minnesota: Amur corktree $(n=5)$, river birch $(n=7)$, striped maple $(n=10)$, swamp white oak $(n=4)$, western redcedar $(n=8)$. Samples collected in Wisconsin: apple $(\mathrm{n}=21)$. The very small size class roots $(0.1$ and $0.2 \mathrm{~mm}$ diameter) seen in the Amur corktree distributions are most likely artifacts due to scanning sections of stele exposed by cortical tissue breaks.

attached to roots; this could be a factor in the greater damage seen in the Minnesota samples. We did not characterize soil physical characteristics other than soil moisture.

Median root diameter was not related to susceptibility to damage from air excavation. Among the ornamental species sampled, striped maple had the lowest level of damage from either air excavation or root elutriation (Fig. 2), despite having a similar median root diameter to river birch and swamp white oak (Fig. 1, Table 1). River birch experienced

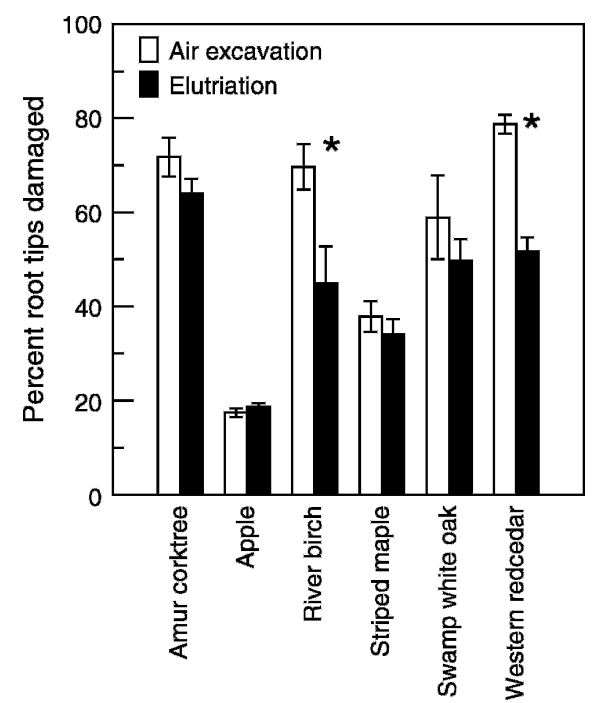

Fig. 2. Root damage in samples (\% damaged roots out of total root tips observed) collected by air excavation and hydropneumatic elutriation of soil cores. A significant sampling treatment effect on root damage $(P<0.05)$ is indicated by $*$. Values are mean \pm SE. Samples collected in Minnesota: river birch $(\mathrm{n}=7)$, Amur corktree $(\mathrm{n}=5)$, striped maple $(\mathrm{n}=10)$, swamp white oak $(n=4)$, western redcedar $(n=8)$. Samples collected in Wisconsin: apple $(\mathrm{n}=21)$.

with air-excavation samples. In air excavation, we deliberately sampled entire root clusters attached to scaffold roots for each sample. In contrast, the probability of sampling an entire root cluster in a soil core was $<1$ due to the random nature of sampling and the relative scarcity of scaffold roots vs. fine roots.

Although soil moisture differed among the locations sampled in Minnesota, there was no significant correlation between root damage and soil moisture. Because soil strength is lower in wetter soil (Hillel, 1982), we hypothesized that the lowest root damage would be found in plots with the wettest soil. The wettest soil was found in the plot of swamp white oak, and the driest soil in the plot of striped maple, but air-excavation root damage was much greater in swamp white oak.

Both root and soil mechanical properties are potential factors controlling the extent of root tip damage during sampling. Soil strength and aggregation may be important soil factors; the shearing damage we commonly observed would be consistent with loss of root tips embedded in soil aggregates. It is not known if the root tip damage is due to torsional or axial forces, although both are likely to be present during both air excavation and root elutriation. There are likely to be differences in root strength associated with variation among species and among roots within a tree in resistance to damage.

Root strength is expected to be closely related to root anatomy. The root hypodermis consists of one or more subepidermal cortical layers differentiated as a protective tissue containing suberin lamellae on the inside 
of the primary wall and is often lignified (Esau, 1977); the presence of a hypodermis should increase the resistance of the root to mechanical damage. A root hypodermis is common in roots of gymnosperms and angiosperms (Esau, 1977) and was seen in all species except for Amur corktree. Fine roots of Amur corktree lacked a well-defined hypodermis and were quite susceptible to damage from both types of root harvesting, with damage to $>72 \%$ of root tips. We observed that the cortex was either partially or totally stripped off the stele in many Amur corktree roots. This damage was also evident in the bimodal distribution of root diameters in Amur corktree (Fig. 1); much of the Amur corktree root length in the $0.1-$ and $0.2-\mathrm{mm}$ diameter size class for is likely an artifact due to imaging of roots stripped of cortical tissue. In contrast, roots of striped maple, with a well-defined hypodermis, were relatively resistant to cortical damage and root tip loss during harvest. Acer species have robust root hypodermis development; Withington et al. (2006) observed the thickest root hypodermis suberization in Norway maple (Acer planatoides L.) and sycamore maple (A. pseudoplatanus L.) in their study of 11 tree species. The presence of a thick hypodermis in these two Acer species was associated with longer root lifespans than the other deciduous species in this study (Withington et al., 2006).

Both sampling methods have advantages and disadvantages in harvesting fine roots. Root elutriation is well-suited to quantitative analysis of root-length density in soil cores and has been commonly used in a large number of studies. The equipment needed to collect soil cores is inexpensive, but the system used for hydropneumatic elutriation is fairly costly $(\approx \$ 6,000)$ and not readily portable. Roots subject to hydropneumatic elutriation are washed quite clean during normal processing; however, root samples obtained from elutriation are often mixed with organic matter and roots of nontarget species, requiring time-consuming sample sorting.

Air excavation would be difficult to use for quantitative analysis of root-length density; sampling a known soil volume is difficult in air excavation. The requirement for a large air compressor $\left(6.21 \times 10^{5} \mathrm{~Pa}, 7.1 \times 10^{-2}\right.$ $\left.\mathrm{m}^{3} \cdot \mathrm{s}^{-1}\right)$ is a major cost and limitation of airexcavation sampling of roots; compressors of this size cannot easily be used at sites away from road access. Lower flow rate nozzles are available that could be used with smaller compressors, but their effectiveness in root excavation has not been tested. As discussed by Rizzo and Gross (2000), roots sampled by air excavation may require some washing to remove rhizosphere soil. In contrast to elutriation of soil core samples, organic matter is typically removed during air excavation, and nontarget roots are easily identified by inspection, making isolation of target species roots simpler. This is a significant advantage when collecting roots within a mixed-species landscape. Air excavation allows identification of the source tree for root samples. This is of particular value in sampling for analysis of genotypic effects on root traits in a planting with overlapping root systems (e.g., Kosola et al., 2004)

Choice of a root sampling method will depend upon the requirements of the individual study and characteristics of the site. If root damage is to be minimized, hydropneumatic elutriation may have a slight edge over air excavation. It is noteworthy that, despite the use of a supersonic air jet, air excavation caused significantly more root damage in only two of the six species sampled in this study. While root characteristics must certainly determine susceptibility to damage during sampling, fine-root diameter was not a good predictor of the likelihood of damage by either sampling method. For species such as Amur corktree that lack a root hypodermis, sampling intact roots is likely to be difficult with either air excavation or root elutriation; slower, gentler methods of washing soil from roots would have to be developed.

\section{Literature Cited}

Boke, N.H. 1970. Clearing and staining plant materials with lactic acid and pararosaniline hydrochloride. Proc. Okla. Acad. Sci. 49:1-2.

Bouma, T.J., K.L. Nielsen, and B. Koutstaal. 2000 Sample preparation and scanning protocol for computerised analysis of root length and diameter. Plant Soil 218:185-196.

Brundrett, M., G. Urase, and B. Kendrick. 1990. Comparative anatomy of roots and mycorrhizae of common Ontario trees. Can. J. Bot. 68 551-578.

Comas, L.H., T.J. Bouma, and D.M. Eissenstat. 2002. Linking root traits to potential growth rate in six temperate tree species. Oecologia 132:34-43.

Esau, K. 1977. Anatomy of seed plants. Wiley, New York, $550 \mathrm{p}$.

Fitter, A.H. 1987. An architectural approach to the comparative ecology of plant root systems. New Phytol. 106:61-77.

Guo, D.L., R.J. Mitchell, and J.J. Hendricks. 2004. Fine root branch orders respond differentially to carbon source-sink manipulations in a longleaf pine forest. Oecologia 140:450-457.

Hillel, D. 1982. Introduction to soil physics. Academic Press, New York, $364 \mathrm{p}$.

King, J.S., K.S. Pregitzer, D.R. Zak, W.E. Holmes, and K. Schmidt. 2005. Fine root chemistry and decomposition in model communities of north-temperate tree species show little response to elevated atmospheric $\mathrm{CO}_{2}$ and varying soil resource availability. Oecologia $146: 318-328$

Kosola, K.R., D.I. Dickmann, R.B. Hall, and B.A.A. Workmaster. 2004. Cottonwood growth rate and fine root condensed tannin concentration. Tree Physiol. 24:1063-1068.

Kosola, K.R., D.I. Dickmann, E.A. Paul, and D. Parry. 2001. Repeated insect defoliation effects on growth, nitrogen acquisition, carbohydrates, and root demography of poplars. Oecologia 129:65-74.

Kosola, K.R., D. Parry, and B.A.A. Workmaster 2006. Responses of condensed tannins in poplar roots to fertilization and gypsy moth defoliation. Tree Physiol. 26:16071611.

Livesley, S.J., C.L. Stacey, P.J. Gregory, and R.J. Buresh. 1998. Sieve size effects on root length and biomass measurements of maize ( $\mathrm{Zea}$ mays) and Grevillea robusta. Plant Soil 207:183-193.

Nadezhdina, N. and J. Cermak. 2003. Instrumental methods for studies of structure and function of root systems of large trees. J. Expt. Bot. 54:1511-1521.

Pallant, E., R.A. Holmgren, G.E. Schuler, K.L. McCracken, and B. Drbal. 1993. Using a fine root extraction device to quantify small diameter corn roots $(<0.025 \mathrm{~mm})$ in field soils. Plant Soil 153:273-279.

Pregitzer, K.S., M.E. Kubiske, C.K. Yu, and R.L. Hendrick. 1997. Relationships among root branch order, carbon, and nitrogen in four temperate species. Oecologia 111:302-308.

Rizzo, D.M. and R. Gross. 2000. Distribution of Armillaria on pear root systems and a comparison of root excavation techniques, p. 305-311. In: A. Stokes (ed.). The supporting roots of trees and woody plants: form, function and physiology. Kluwer Academic Publishers, Dordrecht.

Rizzo, D.M., E.C. Whiting, and R.B. Elkins. 1998. Spatial distribution of Armillaria mellea in pear orchards. Plant Dis. 82:1226-1231.

Smiley, E.T. 1999. Air excavation: the next arboricultural frontier. Arbor Age 19:8-10.

Smucker, A.J.M., S.L. McBurney, and A.K. Srivastava. 1982. Quantitative separation of roots from compacted soil profiles by the hydropneumatic elutriation system. Agron. J. 74:499-503.

Withington, J.M., P.B. Reich, J. Oleksyn, and D.M. Eissenstat. 2006. Comparisons of structure and life span in roots and leaves among temperate trees. Ecol. Monogr. 76:381-397. 